\title{
Isolation of actinomycetes from maize rhizosphere from Kupang, East Nusa Tenggara Province, and evaluation of their antibacterial, antifungal, and extracellular enzyme activity
}

\author{
Umi Fatmawati ${ }^{1, *}$, Yulin Lestari ${ }^{2}$, Anja Meryandini $^{2}$, Abdjad Asih Nawangsih $^{3}$, and Aris Tri Wahyudi ${ }^{2}$ \\ ${ }^{1}$ Graduate School of Bogor Agricultural University, Microbiology Study Program, Department of Biology, Faculty of Mathematics and \\ Natural Sciences, Jalan Meranti, Kampus IPB Darmaga, Bogor 16680, Indonesia \\ ${ }^{2}$ Department of Biology, Faculty of Mathematics and Natural Sciences, Bogor Agricultural University, Jalan Meranti, Kampus IPB Darmaga, \\ Bogor 16680, Indonesia \\ ${ }^{3}$ Department of Plant Protection, Faculty of Agricultural Technology, Bogor Agricultural University, Gedung Fateta, Kampus IPB Darmaga \\ PO Box 220, Bogor 16002, Indonesia \\ *Corresponding author: fatmawatiumi12@gmail.com
}

SUBMITTED 22 September 2017 REVISED 6 February 2018 ACCEPTED 25 February 2018

\begin{abstract}
Actinomycetes are one of the components of the rhizospheric microbial population and useful for producing secondary metabolites such as lytic enzymes, antibiotics, and antifungals. The aim of this study was to isolate actinomycetes from the rhizosphere of maize collected from Kupang, East Nusa Tenggara Province, Indonesia. The screening was focused on the actinomycetes that showed the ability to produce antibacterial, antifungal, and extracellular enzymes such as amylase, cellulase, and protease. The actinomycetes were isolated using Humic-Acid Vitamin B (HV) agar media. The antagonistic assay was tested against Escherichia coli, Staphylococcus aureus, Sclerotium rolfsii, and Fusarium oxysporum. Isolate JKP-8 was an isolate that showed the highest activity in inhibiting the growth of E. coli and S. aureus bacteria. Isolate JKP-5 showed the highest activity in inhibiting the growth of F. oxysporum. There were no actinomycete isolates that showed an ability to inhibit the growth of the S. rolfsii fungus based on a dual culture assay. JKP-3 and JKP-4 isolates exhibited the highest ability to hydrolyze amylum, while JKP-5 and JKP-8 isolates exhibited the highest ability to hydrolyze CMC. The results of the amplification of the 16S rRNA gene in isolates JKP 5 and JKP 8 indicated that both isolates belong to Streptomyces.
\end{abstract}

KEYWORDS actinomycetes; antibacterial; antifungal; hydrolytic enzyme; rhizosphere

\section{Introduction}

The plant rhizosphere is a unique biological niche with various micro floras consisting of bacteria, fungi, protozoa and, algae. The community is supported by nutrients from organic material, which comes from plant roots, and root exudates, which has important benefits for microbial growth. Root exudates are compounding produced by plant roots and secreted surrounding the plant rhizosphere. Root exudates could be a sugar compound, amino acid, enzyme, vitamin, organic acid, nucleotide, antibiotic, phenolic compound, or other types of compounds (Rovira 1969). Variation root exudates composition is determined by the type of plant, growth phase, and physical factor like $\mathrm{pH}$, type of soil, humidity, temperature, and the presence of microorganisms (Huang et al. 2014). The existence of root exudates in the plant rhizosphere is closely related to the interaction between microorganisms and plant which can be beneficial or disadvantageous.
Maize is one of the crop commodities which is widely cultivated in Indonesia, especially in a dry field as in the Kupang region in East Nusa Tenggara Province (ENT). Maize is featured agricultural product with the productivity of 588, 90-kiloton per year of 50\% agricultural area in ENT. In a monoculture planting, maize may be viewed as an ecosystem engineer strongly responsible for shaping the agricultural environment for cohabitating species. It is indicated by the ability of plant roots to produce various root exudates which associated with the environmental change like soil properties, $\mathrm{pH}$, temperature, water content, nutrient availability and microbe population to promote plant growth and plant development (Peiffer et al. 2013). Nowadays, a lot of research has been done about the diversity of microorganisms surrounding plant rhizosphere and the study about the potential microbe for promoting plant growth and biocontrol for plant pathogen.

Actinomycete is a Gram-positive bacterium that is widely distributed in nature. The most dominant discov- 
ered actinomycetes from soil are those belonging to the Streptomyces genus. Actinomycetes have an important role in degrading organic compounds and produce bioactive compounds like antibiotic, enzyme and phytohormone. Several actinomycetes which produce hydrolytic enzymes such as: chitinase produced from Streptomyces viridian, cellulase produced from Thermonospora spp., peptidase and protease produced from Nocardia spp., xylanase produced from Microbispora spp., ligninase produced from Nocardia autotrophica, amylase produced from Thermomonospora curvata, sugar isomerase produced from Actinoplanes missouriensis, pectinase, hemicellulase, and keratinase (Solans and Vobis 2003; Macagnan et al. 2008).

The role of actinomycetes as a biocontrol for soil borne plant pathogen has been widely applied to some plant pathogenic fungi like Fusarium spp. (Gopalakrishnan et al. 2011), Pythium spp. (Hamdali et al. 2008), Rhizoctonia spp. (Sadeghi et al. 2006), and Verticillium spp. (Meschke and Schrempf 2010). Some actinomycetes strains have also been formulated into a commercial product such as Streptomyces griseoviridis which are used to protect the plant from Fusarium spp. and Alternaria spp. infection (Lahdenperä et al. 1991).

The study was undertaken to explore actinomycetes from a maize rhizosphere collected from Kupang, ENT. The aim of this research was to obtain the potential actinomycetes that have antibacterial and antifungal activity, and produce some extracellular enzymes such as cellulase, protease, and amylase. The benefit of the research is to obtain the potential isolates of actinomycetes from maize rhizosphere collected from Kupang, ENT, which have the ability in pathogen biocontrol and hydrolytic enzyme production.

\section{Materials and methods}

\subsection{Actinomycetes isolation}

The sample was taken from maize rhizospheric soil collected from Kupang, ENT, according to Ashokvardhan et al. (2014). Soil samples were taken from the root area with the depth of 5-10 cm. Samples were kept in sterile plastic bags and tightly closed for further analysis for actinomycetes. The soil sample was incubated in the oven in $60^{\circ} \mathrm{C}$ for $2 \mathrm{~h}$. When the soil drying, the sample were mashed using a sterile mortar and suspended into $100 \mathrm{~mL}$ distilled water. One $\mathrm{mL}$ the mixture is diluted in $9 \mathrm{~mL}$ distilled water gradually to the level of dilution $10^{-5}$. Pipette $0.01 \mathrm{~mL}$ of dilution $10^{-3}, 10^{-4}$ and $10^{-5}$ were spread into Humic-Acid Vitamin Agar (HVA) in duplicate. The composition of HVA medium refers to Hayakawa and Nonomura (1987) (1 g Humic Acid, 0.5 g Na $2 \mathrm{HPO}_{4}, 1.71 \mathrm{~g} \mathrm{KCl}$, 0.05 g MgSO$_{4} .7 \mathrm{H}_{2} \mathrm{O}, 0.01 \mathrm{CuSO}_{4} .7 \mathrm{H}_{2} \mathrm{O}, 0.02$ g CaCO$_{3}$, Vit B, $50 \mathrm{mg}$ Cyclohexamide, $50 \mathrm{mg}$ nalidixic acid $18 \mathrm{~g}$ Agar, 1,000 $\mathrm{mL}$ distilled water ( $\mathrm{pH} 7.2)$ ). The medium was incubated at a temperature of $30^{\circ} \mathrm{C}$ for $21 \mathrm{~d}$. The acti- nomycetes grown on the medium were isolated, purified, and identified. Isolation and purification were performed in three kinds of medium, ISP-2 agar, YSA, and ISP-4 agar. The composition of the medium refers to Shirling and Gottlieb (1966) (ISP-2 ISP-2 10 g Malt extract, 4 g yeast extract, $4 \mathrm{~g}$ glucose, and $20 \mathrm{~g}$ agar ( $\mathrm{pH}$ 7.2)). The composition of ISP-4 medium agar consist of $10 \mathrm{~g}$ soluble starch, $1 \mathrm{~g} \mathrm{~K}_{2} \mathrm{HPO}_{4}, 1 \mathrm{~g} \mathrm{MgSO} 4.7 \mathrm{H}_{2} \mathrm{O}, 1 \mathrm{~g} \mathrm{NaCl}, 2$ $\mathrm{g}\left(\mathrm{NH}_{4}\right)_{2} \mathrm{SO}_{4}, 2 \mathrm{~g} \mathrm{CaCO} 3,500 \mathrm{~mL}$ distilled water, $1 \mathrm{ml}$ trace salt solution, $20 \mathrm{~g}$ Agar ( $\mathrm{pH}$ 7.2) (Shirling and Gottlieb 1966). The colony of actinomycetes which have a different morphological feature was transferred into ISP-2 medium agar for identification and assay of antibacterial and antifungal properties.

\subsection{Morphological characterization of actinomycetes}

Determination of isolate characteristics was conducted on ISP-2 medium agar, ISP-4 medium agar, and YSA for 7 $\mathrm{d}$ incubation at a temperature of $30^{\circ} \mathrm{C}$. The colony characterization was determined using a color grouping of aerial mycelium, substrate mycelium, and solubilizing pigment formation parameter. Chain spore morphology was observed using microscopic slide culture under 40x and 100x magnification.

\subsection{Antagonistic assay of actinomycetes towards Staphylococcus aureus, Escherichia coli, Scle- rotium rolfsii and Fusarium oxysporum}

Antibacterial activity was determined using the plug agar method on ISP-2 medium agar which had been inoculated with $4 \mathrm{~mL} E$. coli and $S$. aureus with an optimum concentration of $10^{8} \mathrm{CFU} / \mathrm{mL}$. One disk of actinomycetes agar (diameter $8 \mathrm{~mm}$ ) was inoculated on the surface of ISP-2 medium agar containing a bacterial culture. The observation was made after $24 \mathrm{~h}$ incubation at a temperature of $37^{\circ} \mathrm{C}$. A clear zone formed around the colony to indicate the inhibition of bacterial growth. The inhibition index was measured using the formula: $d 2-d 1$, with $d 1$ showing the diameter of the actinomycetes colony and $d 2$ showing the diameter of the actinomycetes colony and clear zone formed. If $\Delta d>=20 \mathrm{~mm}(+++), \Delta d 10-19 \mathrm{~mm}(++)$, $\Delta d 5-9 \mathrm{~mm}(+)$, and $\Delta d<5 \mathrm{~mm}(-)$.

The antifungal assay was conducted using a dual culture assay, where actinomycetes isolates were grown together with pathogenic fungi on ISP-2 medium agar. One disk of 7 days old of actinomycetes culture was incubated together with the tested fungi. The actinobacteria were streaked at a distance $3 \mathrm{~cm}$ from $S$. rolfsii and F. oxysporum. Antagonistic isolates will show the inhibition of concentric growth of fungus on the Petri dishes. The percentage of inhibition of the fungus radial growth are calculated using the formula $1-(a / b) \times 100 \%$, where $a$ indicates the distance between the center of the fungus towards actinomycetes isolates and $b$ shows the distance between the center of the fungus to the direction side opposite to actinomycetes isolates (Dikin et al. 2006). 


\subsection{Isolates producing hydrolytic enzyme identifica- tion}

A qualitative assay of enzymatic activity was conducted using the plug agar method. Assay of extracellular enzymatic activity for amylase, cellulase, and protease was inoculated on ISP-2 medium agar. The substrate used for testing the enzyme activity was amylum for amylase activity, CMC for cellulose activity, and skim milk for protease activity, as much as $1 \%(\mathrm{w} / \mathrm{v})$, respectively. Detection of clear zone formation of amylase enzyme activity assay using $0.1 \%$ of Lugol solution. To enable the detection of the hydrolytic zone as a result of cellulase enzyme activity, $0.1 \%$ congo red solution was added for $15 \mathrm{~min}$ and rinsed with $1 \% \mathrm{NaCl}$ for $15 \mathrm{~min}$. The clear zone formed surrounding the colony of actinomycetes indicate the ability of isolates in hydrolyzing amylum, cellulose, and protein. Hydrolytic enzyme index was calculated using this formula:

$$
I H=(d 2-d 1) / d 1
$$

where IH is the index of hydrolytic enzyme, d1 is the diameter of the actinomycetes colony and $\mathrm{d} 2$ is the diameter of the actinomycetes colony and clear zone formed.

\subsection{Molecular identification of potential isolates using 165 rRNA gene}

The isolates with the highest antibacterial and antifungal potential were purified using the quadrant method and rejuvenated by streaking it on YMA agar. Selected actinomycetes isolates were further identified using the 16S rRNA gene. The total genomic of the bacteria were isolated using a special bacterial isolation kit (Presto ${ }^{\mathrm{TM}}$ Mini Kit, Geneaid), with the procedure following the manufacturer's instructions. The first PCR was performed using a specific primer of actinomycetes $27 \mathrm{~F}$ (5'-AGAGTTTGATCCTGGCTCAG-3') (Bruce et al. 1992) and 16Sact1114R (5'-GAGTTGACCCCGGCRGT3’) (Kyselková et al. 2008). The PCR reaction was performed in a total volume of $50 \mu \mathrm{L}$, containing $2.5 \mu \mathrm{L}$ of DNA polymerase enzyme GoTaq Green (Promega), 2.5 $\mu \mathrm{L}$ of each primer (10 pmol), $15 \mu \mathrm{L}$ of nuclease-free water, and $5 \mu \mathrm{L}$ of DNA template. The PCR condition used was pre-denaturation $\left(95^{\circ} \mathrm{C}, 2 \mathrm{~min}\right)$, denaturation $\left(95^{\circ} \mathrm{C}\right.$, $30 \mathrm{~s})$, annealing $\left(55^{\circ} \mathrm{C}, 30 \mathrm{~min}\right)$, elongation $\left(72^{\circ} \mathrm{C}, 1 \mathrm{~min}\right)$, and post-PCR $\left(72^{\circ} \mathrm{C}, 7 \mathrm{~min}\right)$ for 30 cycles. The raw sequencing data were trimmed and assembled using Seqtrace 0.9. Assembling data were further analyzed using the Blast tool from the National Center for Biotechnology Information (NCBI). Furthermore, data were aligned using MEGA 6.0 (Tamura et al. 2011). A phylogenetic tree was subsequently constructed to show the affiliation of actinomycetes isolates JKP5 and JKP8 and other nonactinomycetes using the Neighbor-Joining method with 1,000 bootstrap replications.

\section{Results}

\subsection{Isolates morphological characterization}

A total of 40 isolates collected from the maize rhizosphere were successfully purified on the medium ISP-2 agar. Some of these isolates have the different texture of the surface, the color of the aerial and substrate mycelium. There are 12 isolates indicate a different morphological feature of the colony which shows different strain. The morphological characterization of 12 isolates is shown in Figure 1. The observations of the isolates grown on the medium ISP-2 for $10 \mathrm{~d}$ showed the diversity of aerial mycelium, mycelium substrate: white, beige, light brown and dark brown. Based on the mycelium color grouping, most isolates can be classified into the genus of Streptomyces. Streptomyces have a diversity in spore chain forms such as reflexibiles, spira, retinaculaperti, and verticillate ( $\mathrm{Li}$ et al. 2016). This was also highlighted by Alimuddin et al. (2011), who identified the actinomycetes of the eucalyptus rhizosphere in the oatmeal medium to obtain the colonies with spore chains morphology and aerial mycelium and nearly similar substrate colors in the range of white, yellow, light brown and dark brown.

\subsection{Antagonistic activity of actinomycetes isolated from maize rhizosphere}

The antibacterial activities of actinomycetes isolated from maize rhizosphere were tested using the plug agar method on ISP-2 agar. The agar had been inoculated with $E$. coli and $S$. aureus bacteria with a total cell number of $10^{8}$ $\mathrm{CFU} / \mathrm{mL}$. Antibacterial activity results were observed after 24-h incubation by measuring the diameter of a clear zone formed surrounding actinomycetes colonies. Meanwhile, to determine the ability of isolates in inhibiting the growth of pathogenic fungi, a dual culture assay was conducted between actinomycetes and the fungi, S. rolfsii and F. oxysporum fungi were grown together on ISP-2 agar and incubated for $7 \mathrm{~d}$. The antifungal activity results were observed with the growth zone of the fungus growth heading to the actinomycetes isolates were listed in Table 1.

All of the actinomycetes isolates had the ability to inhibit $E$. coli and S. aureus during $24 \mathrm{~h}$ incubation. The highest activity of actinomycetes inhibition against the growth of E. coli and S. aureus was JKP-8, as shown in the difference between the clear zone diameter formed against the growth of actinomycetes, which was $8.5 \mathrm{~mm}$ in E. coli and $8.7 \mathrm{~mm}$ in $S$. aureus. In genus, the 12 actinomycetes isolates had a light activity to inhibit bacterial growth.

Based on the antagonistic test of actinomycetes isolates from maize rhizosphere towards fungus, none of the isolates were found to be able to inhibit $S$. rolfsii, whereas most of them appeared to be able to inhibit the growth of F. oxysporum. The highest level of antifungal activity was shown by JKP-5, at $42.8 \%$ inhibition. The antibacterial and antifungal activities by JKP-8 and JKP-5 are shown in Figure 2. 

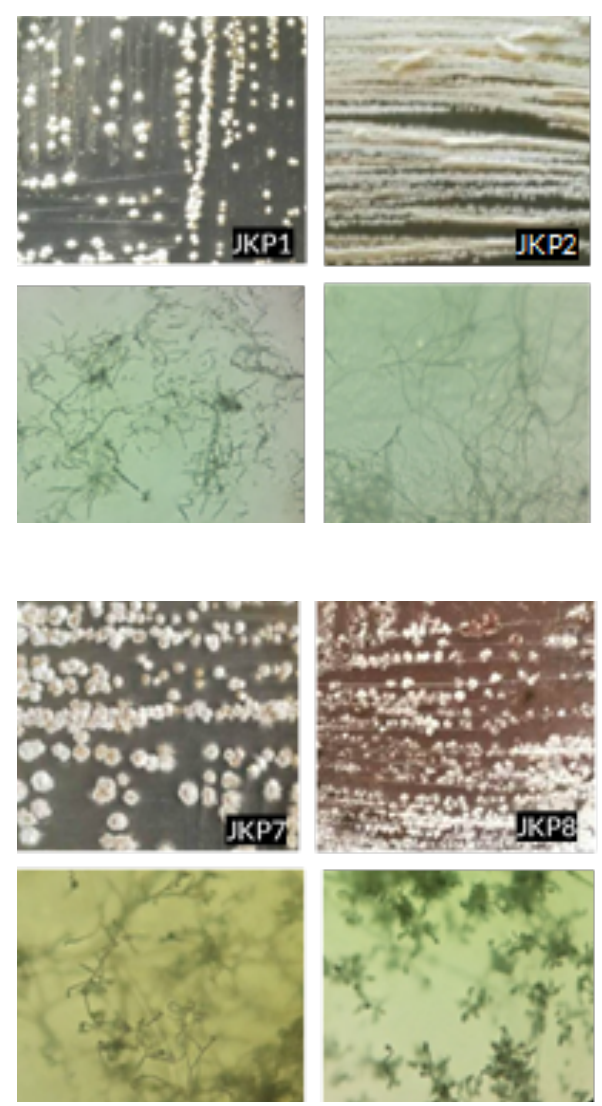
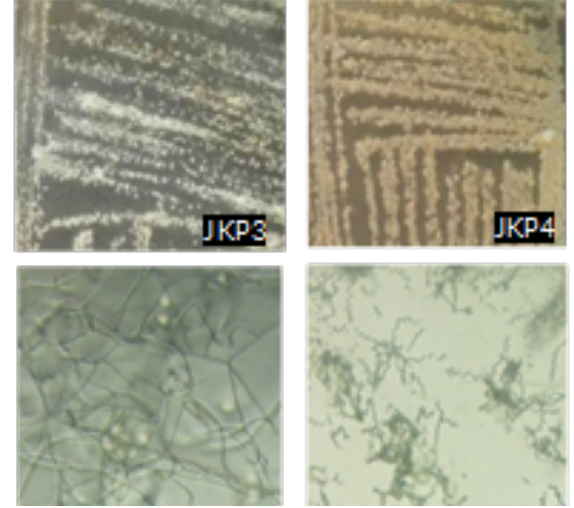

(a)
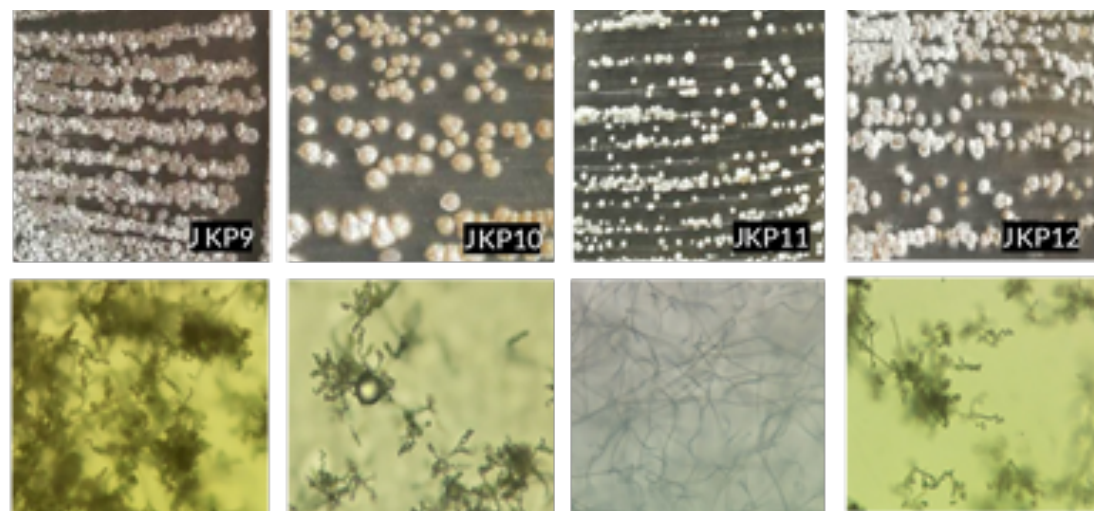

(b)

FIGURE 1 Variation of colony morphology of Actinomycetes from maize rhizosphere after seven days of incubation at YMA media (a). The type of spore chains Actinomycetes. was observed by a light microscope using 100x magnification (b).

\subsection{Extracellular enzyme production of actinomycetes isolated from maize rhizosphere}

Screening of extracellular enzyme production was done to determine the ability of actinomycetes from maize rhizosphere in producing hydrolytic amylase, cellulase and, protease using agar plug method. In this assay, the ISP2 medium was added with starch, CMC and skim each $1 \%(w / v)$. Detection of extracellular enzyme production by actinomycetes was conducted by calculating the hydrolytic index based on the diameter of the hydrolytic zone formed around the actinomycetes colony. The results of hydrolysis amylum, cellulose, and skim milk by actinomycetes are presented in Table 2.

Twelve actinomycetes isolates were tested show the ability to hydrolyze complex compounds of amylum, cellulose and skim milk. JKP-3 and JKP-4 isolates have the highest ability to hydrolyze the starch, as indicated by the hydrolytic index of 2.75. While in hydrolyzing cellulose, the highest ability was shown by JKP-5 and JKP-8 isolates with the hydrolytic index of 4 . The isolates having the highest ability to hydrolyze the skim were JKP-4 with a hydrolytic index of 3.25. The formation of clear or halo zone in ISP2 + amylum medium can be observed visually with the addition of $1 \%$ Lugol solution, while clear zone observation results of cellulose hydrolysis at ISP-2

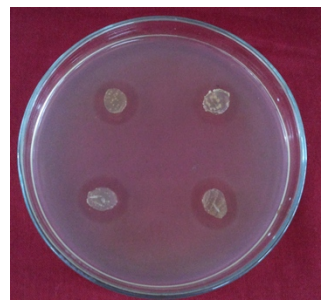

(a)

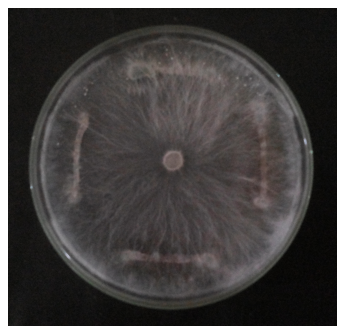

(c)

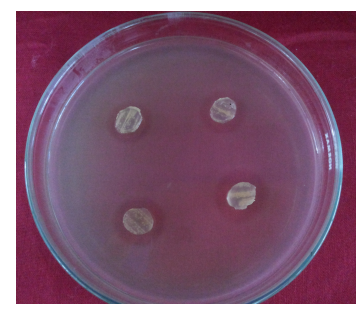

(b)

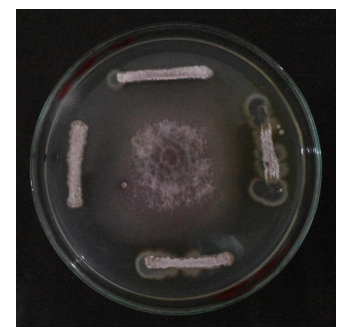

(d)
FIGURE 2 Antibacterial activity of JKP-8 towards (a) E. coli and (b) S. aureus, and antifungal activity of JKP-5 towards (c) S. rolfsii and (d) F. oxysporum.

+ CMC medium by adding Congo red solution $0.1 \%$ and washing with $1 \% \mathrm{NaCl}$ solution. The results of hydrolytic hydrolysis, cellulose, and actinomycetes isolate schemes are shown in Figure 3. 
TABLE 1 Antibacterial and antifungal activity of actinomycetes isolated from maize rhizosphere.

\begin{tabular}{lllllllll}
\hline \multirow{2}{*}{ Isolates } & E. coli & \multicolumn{5}{c}{ S. aureus } & \multirow{2}{*}{ S. rolfsii (\%) } & F. oxysporum (\%) \\
\cline { 2 - 6 } & $\mathrm{d} 1(\mathrm{~mm})$ & $\mathrm{d} 2(\mathrm{~mm})$ & $* \Delta \mathrm{d}$ & $\mathrm{d} 1(\mathrm{~mm})$ & $\mathrm{d} 2(\mathrm{~mm})$ & $* \Delta \mathrm{d}$ & \\
\hline JKP-1 & 16.2 & 9 & $7.2(+)$ & 15.8 & 8.8 & $7(+)$ & - & - \\
JKP-2 & 14.8 & 9 & $5.8(+)$ & 15.5 & 8.8 & $6.7(+)$ & - & 18.0 \\
JKP-3 & 16.5 & 9.1 & $7.3(+)$ & 16.8 & 9 & $7.8(+)$ & - & 30.3 \\
JKP-4 & 16.8 & 9.3 & $7.5(+)$ & 15.8 & 9 & $6.8(+)$ & - & 24.2 \\
JKP-5 & 17 & 9.3 & $7.7(+)$ & 15.3 & 9 & $6.3(+)$ & - & 42.8 \\
JKP-6 & 17.3 & 9 & $8.3(+)$ & 14 & 8.8 & $5.2(+)$ & - & 28.5 \\
JKP-7 & 16.6 & 8.8 & $7.8(+)$ & 17.2 & 9.3 & $7.8(+)$ & - & 34.2 \\
JKP-8 & 17 & 8.5 & $8.5(+)$ & 17.4 & 8.7 & $8.7(+)$ & - & 22.8 \\
JKP-9 & 14.8 & 8.5 & $6.3(+)$ & 14.3 & 9.3 & $5(+)$ & - & 25.0 \\
JKP-10 & 14.5 & 9 & $5.5(+)$ & 13.3 & 9.2 & $4.2(+)$ & - & - \\
JKP-11 & 14.3 & 8.8 & $5.5(+)$ & 14.7 & 9 & $5.7(+)$ & - & 22.8 \\
JKP-12 & 14.7 & 9 & $5.7(+)$ & 15 & 9 & $6(+)$ & - & 22.8 \\
\hline
\end{tabular}

$\mathrm{d} 1$ = diamater of the colony actinomycetes

$\mathrm{d} 2=$ diamater of the colony actinomycetes and clear zone

*If $\Delta(\mathrm{d} 2-\mathrm{d} 1)<1 \mathrm{~mm}(-)$ : no activity, $\Delta(\mathrm{d} 2-\mathrm{d} 1)=1-10 \mathrm{~mm}(+)$ : light activity, $11>\Delta(\mathrm{d} 2-\mathrm{d} 1)>20 \mathrm{~mm}(++)$ : temperate activity, $\Delta(\mathrm{d} 2-\mathrm{d} 1)>20$ $\mathrm{mm}(+++)$ : high activity

TABLE 2 Hydrolytic activity of extracellular enzyme produced by actinomycetes from maize rhizosphere.

\begin{tabular}{llll}
\hline \multirow{2}{*}{ Isolates } & \multicolumn{3}{c}{ Index of hydrolytic enzyme (IH) } \\
\cline { 2 - 4 } & $\begin{array}{l}\text { ISP- } \\
\text { 2+Amylum }\end{array}$ & ISP-2+CMC & $\begin{array}{l}\text { ISP-2+Skim } \\
\text { Milk }\end{array}$ \\
\hline JKP-1 & 2.125 & 2.75 & 2.75 \\
JKP-2 & 2.125 & 3.375 & 2.5 \\
JKP-3 & 2.75 & 2.75 & 2 \\
JKP-4 & 2.75 & 2.125 & 3.25 \\
JKP-5 & 2.5 & 4 & 3 \\
JKP-6 & 1.125 & 3.75 & 2.25 \\
JKP-7 & 1.125 & 2.75 & 2.125 \\
JKP-8 & 1.75 & 4 & 2.75 \\
JKP-9 & 1.875 & 3.375 & 3 \\
JKP-10 & 1.25 & 2.75 & 1.5 \\
JKP-11 & 1.75 & 2.5 & 2 \\
JKP-12 & 1.75 & 2.625 & 2.375 \\
\hline
\end{tabular}

\subsection{Molecular identification of potential isolates}

Molecular identification was performed on the isolates that had the best antagonistic and hydrolysis activity, i.e. JKP5 and JKP8. The amplification product of the 16S rRNA gene from the selected actinomycetes isolates showed the length of the DNA fragment to be 1080 bp. The alignment results of the partial sequence of the 16S rRNA gene actinomycetes isolates with strains compared with those in GenBank using the BLASTN program showed that the isolates had a resemblance to the Streptomyces genus (Table 3).

\section{Discussion}

Actinomycetes were successfully isolated and characterized from a maize rhizosphere in Kupang, East Nusa Tenggara, with as many as 12 isolates. Morphological identification was based on the morphological variation of the spore chains and the color diversity of the aerial and substrate mycelium. The color of aerial mycelium is white, yellow, beige, gray, light brown, and dark brown on ISP2 medium incubated for $10 \mathrm{~d}$ at $30^{\circ} \mathrm{C}$. Khamna et al. (2010) found that most of the actinomycetes isolated from the rhizosphere of various medicinal plants belong to Streptomyces. The rhizosphere is a unique biological niche that can support the abundance and diversity of saprophytic microorganisms due to the high content of organic material derived from the exudates of roots and plant roots (Merckx et al. 1987). The number of species of microorganisms including actinomycetes in the rhizosphere can fluctuate from thousands to millions per gram. The presence of actinomycetes in plant rhizospheres has specificity based on the strain and plant species (Rovira 1969; Intra et al. 2011). Actinomycetes play an important role in plant growth and microorganism diversity, and may act as providers of carbon monomers from polysaccharide resulted by various extracellular hydrolytic enzymes such as amylase, cellulase, protease, and chitinase produced by actinomycetes (Singh et al. 2004). The positive interaction between actinomycetes and plants are to stimulate the growth of plants by producing phytohormones and nutrient providers for plants, actinomycetes also act as a controlling pathogen derived from the soil by producing various antipathogenic compounds such as siderophores, $\beta$-1, 3-glucanase, chitinase, antibiotics, and cyanide (Shimizu 2011). 


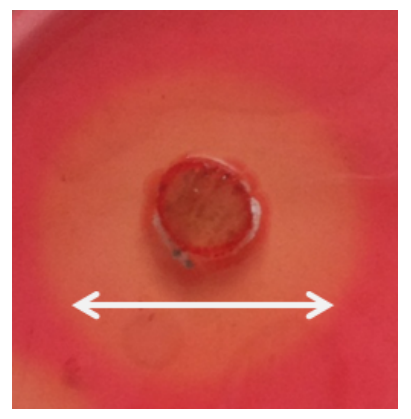

(a)

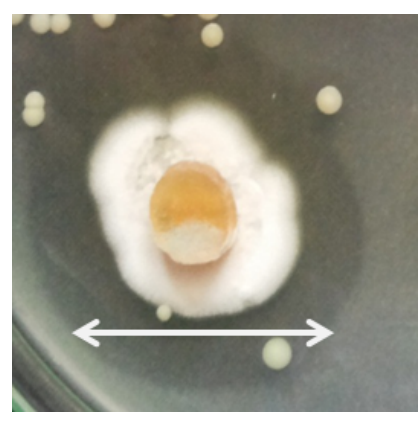

(b)

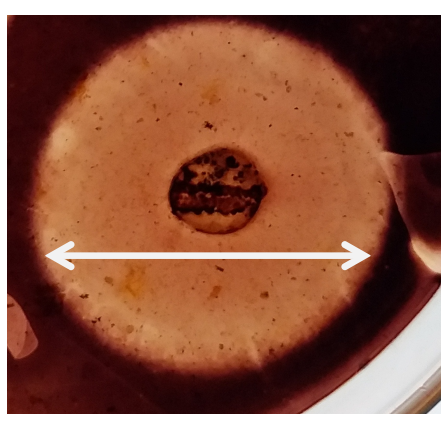

(c)

FIGURE 3 Hydrolytic substrate by actinomycetes isolated from maize rhizosphere on (a) ISP-2 + CMC (1\%), (b) ISP-2 + skim (1\%), (c) ISP-2 + starch (1\%). The arrows indicate the existence of a clear zone formed.

TABLE 3 Percentage of 16 S rRNA gene sequence similarity of isolate JKP5 and JKP8.

\begin{tabular}{llllll}
\hline Isolate & Species Affiliation (GenBank) & Query Cover & E-Value & Similarity & Accession Number \\
\hline JKP5 & Streptomyces cellulosae strain NRRL B-2889 & $99 \%$ & 0.0 & $99 \%$ & NR. 043815.1 \\
JKP8 & Streptomyces pseudogriseolus strain NRRL B-3288 & $99 \%$ & 0.0 & $99 \%$ & NR. 043835.1 \\
\hline
\end{tabular}

Actinomycetes isolated from a maize rhizosphere from Kupang, ENT, has a potential agent as antibacterial and antifungal. It can be seen from the antibacterial assay of actinomycetes towards E. coli and S. aureus, which showed that all of the isolates were able to inhibit the growth of the tested bacteria on ISP-2 agar. The highest inhibition was found in isolate JKP-8. JKP8 has morphological characteristics based on the color of the mycelium being white in the aerial mycelium and brownish red in the substrate mycelium, and it producing dissolved red pigment in ISP-2 agar. Barakate et al. (2002) identified actinomycetes from peas rhizosphere in Morocco have a different color in red and white, and also had a fairly strong percentage of inhibition of about $70 \%$ against some pathogenic bacteria, such as Streptomyces scabies, Staphylococcus aureus, and Bacillus subtilis. Khamna et al. (2010) suggest that the presence of root exudates may serve as biostimulants for Streptomyces sp. to produce antimicrobial compounds. The inhibition of growth by antimicrobial agents produced by actino- mycetes against Gram-negative bacteria was stronger than in Gram-positive bacteria (Barakate et al. 2002).

The result of the antifungal assay by actinomycetes isolated from maize rhizosphere showed that there was inhibition of growth of $F$. oxysporum but did not work on $S$. rolfsii. The research conducted by Sreevidya et al. (2016) revealed that the actinomycetes from pistachio nuts rhizosphere have a higher ability to inhibit the growth of F. oxysporum fungi than $S$. rolfsii. The inability of actinomycetes to inhibit the growth of $S$. rolfsii is due to the growth of the fungus faster than actinobacteria, resulting in competition to obtain the growth space and nutrition between actinomycetes and fungi. The growth of $S$. rolfsii fungi on the medium of PDA is more dominated than actinomycetes and forming a long, rigid, and cotton-like mycelia. Sclerotium was formed one week after fungus grown. The appearance of sclerotium is white clumps, and brown color with oval shape, with a size of 1.1-1.84 mm (Sukamto and Wahyuno 2016). The sclerotium is very resistant to degrade by biological and chemical agents and is a form sur-

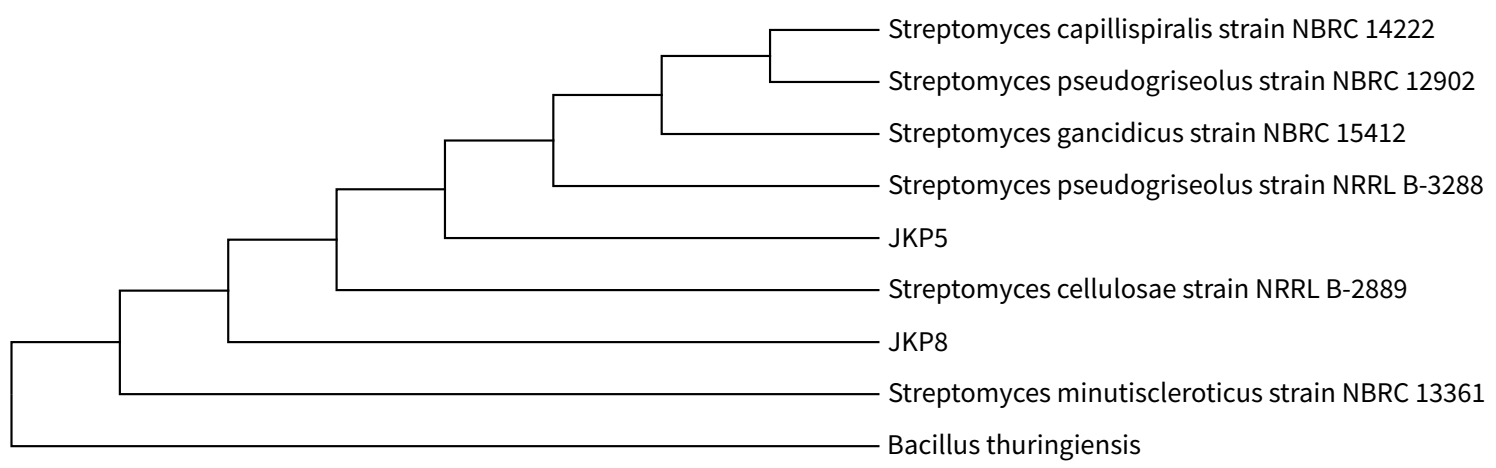

FIGURE 4 Neighbour-joining tree based on 16S rRNA gene sequences, showing the phylogenetic relationship of Isolate JKP5 and JKP8 with a recognized member of the Streptomyces genus. 
vival life of fungus in the soil. The cell wall of sclerotia of $S$. rolfsii contains non-hydrolyzable residue compounds of lipids and carbon content. Acid hydrolysates from sclerotia and hyphae contained 10 and 13 amino acids respectively. Cell wall hyphae contain higher polysaccharides than in sclerotium which is $16 \%$ carbon, $2.3 \%$ hydrogen, and $1.7 \%$ nitrogen (Chet et al. 1967).

The results of hydrolytic assay showed that all actinomycetes from maize rhizosphere have the ability to produce hydrolytic enzymes in the form of amylase, cellulase, and protease. Research on the activity of cellulolytic actinomycetes from palm oil plantation was also done by Kanti (2005), which obtained two isolates from Streptomyces. The strain has the ability to produce cellulase enzyme in 7.7 units and 13.4 units. Jain et al. (2009) revealed that $50 \%$ of actinomycetes isolated from Indian rhizosphere soil were able to produce protease enzymes with the highest activity of 116 units/mL were Streptomyces sampsonii GS 1322. Research by Ting et al. (2014) revealed that isolates of Nocardiopsis sp. and Streptomyces sp. from oil palm plantations have the ability to degrade starch, cellulose, lignin, and xylan into palm oil bunch. The searching for the hydrolytic enzyme from actinomycetes is continuously developed in the framework of its application to industrial, bioremediation and pathogen biocontrol.

\section{Conclusions}

Based on the results, 12 actinomycetes isolates from maize rhizosphere of Kupang, ENT, showed antibacterial and antifungal activities, also produced some extracellular enzymes such as amylase, cellulase, and protease. Isolate JKP-8 is an isolate that had the highest activity in inhibiting the growth of $E$. coli and S. aureus. Isolate JKP- 5 is an isolate that had the highest activity in inhibiting the growth of fungus $F$. oxysporum. All of the isolates were not able to inhibit the growth of $S$. rolfsii based on dual culture assay. The 12 actinomycetes of maize rhizosphere tested had the ability to hydrolyze complex compounds of amylum, cellulose, and protein. JKP-3 and JKP-4 were the isolates which had the highest ability to hydrolyze starch, JKP-5 and JKP-8 had the highest ability to hydrolyze cellulose, and JKP-4 is the highest ability to hydrolyze skim. JKP5 and JKP8 had the highest antibacterial and antifungal activities and starch hydrolyzing activity. These isolates were identified to belong to Streptomyces genus based on the amplification of 16S rRNA gene.

\section{Acknowledgments}

This research was partially supported by a Dissertation Research Grant from the Ministry of Research, Technology and Higher Education, Republic of Indonesia. We would also like to thank all of the staff members of the microbiology laboratory including Mr Jaka and Mrs Heni Rismiyati for their significant inputs in the laboratory.

\section{Authors' contributions}

YL, AM, and ATW who has provided guidance on isolation technique and result analysis. AAN who has provides guidance on the antagonistic test of isolates againts pathogenic fungi. All author read and approved the final version of the manuscript.

\section{Competing interests}

The authors declare no competing of interests.

\section{References}

Alimuddin A, Widada J, Asmara W, Mustofa M. 2011. Antifungal production of a strain of Actinomycetes spp. isolated from the rhizosphere of cajuput plant: selection and detection of exhibiting activity against tested fungi. Indones J Biotechnol. 16(1):1-10. doi:10.22146/ijbiotech.7829.

Ashokvardhan T, Rajithasri A, Prathyusha P, Satyaprasad K. 2014. Actinomycetes from Capsicum annuum L. rhizosphere soil have the biocontrol potential against pathogenic fungi. Int J Curr Microbiol Appl Sci. 3(4):894-903.

Barakate M, Ouhdouch Y, Oufdou K, Beaulieu C. 2002. Characterization of rhizospheric soil streptomycetes from Moroccan habitats and their antimicrobial activities. World J Microbiol Biotechnol. 18(1):49-54. doi:10.1023/A:1013966407890.

Bruce KD, Hiorns WD, Hobman JL, Osborn AM, Strike P, Ritchie DA. 1992. Amplification of DNA from native populations of soil bacteria by using the polymerase chain reaction. Appl Environ Microbiol. 58(10):34133416.

Chet I, Henis Y, Mitchell R. 1967. Chemical composition of hyphal and sclerotial walls of Sclerotium rolfsii Sacc. Can J Microbiol. 13(2):137-141. doi:10.1139/m67-019.

Dikin A, Sijam K, Kadir J, Seman IA. 2006. Antagonistic bacteria against Schizophyllum commune Fr. in Peninsular Malaysia. Biotropia 13(2):111-121. doi:10.11598/btb.2006.13.2.221.

Gopalakrishnan S, Pande S, Sharma M, Humayun P, Kiran BK, Sandeep D, Vidya MS, Deepthi K, Rupela O. 2011. Evaluation of actinomycete isolates obtained from herbal vermicompost for the biological control of Fusarium wilt of chickpea. Crop Prot. 30(8):1070 1078. doi:10.1016/j.cropro.2011.03.006.

Hamdali H, Hafidi M, Virolle MJ, Ouhdouch Y. 2008. Growth promotion and protection against dampingoff of wheat by two rock phosphate solubilizing actinomycetes in a P-deficient soil under greenhouse conditions. Appl Soil Ecol. 40(3):510-517. doi:10.1016/j.apsoil.2008.08.001.

Hayakawa M, Nonomura H. 1987. Humic acid-vitamin agar, a new medium for the selective isolation of soil 
actinomycetes. J Ferment Technol. 65(5):501-509. doi:10.1016/0385-6380(87)90108-7.

Huang XF, Chaparro JM, Reardon KF, Zhang R, Shen Q, Vivanco JM. 2014. Rhizosphere interactions: root exudates, microbes, and microbial communities. Botany 92(4):267-275. doi:10.1139/cjb-2013-0225.

Intra B, Mungsuntisuk I, Nihira T, Igarashi Y, Panbangred W. 2011. Identification of actinomycetes from plant rhizospheric soils with inhibitory activity against $\mathrm{Col}-$ letotrichum spp., the causative agent of anthracnose disease. BMC Res Notes 4:98. doi:10.1186/17560500-4-98.

Jain R, Agrawal SC, Jain PC. 2009. Proteolytic actinomycetes from Indian habitats. J Cult Collect. 6(1):2837.

Kanti A. 2005. Cellulolytic actinomycetes isolated from soil in Bukit Duabelas National Park, Jambi. Biodiversitas 6(2):85-89. doi:10.13057/biodiv/d060203.

Khamna S, Yokota A, Peberdy JF, Lumyong S. 2010. Indole-3-acetic acid production by Streptomyces sp. isolated from some Thai medicinal plant rhizosphere soils. EurAsian J BioSci. 4:23-32. doi:10.5053/ejobios.2010.4.0.4.

Kyselková M, Kopecký J, Felföldi T, Cermák L, Omelka M, Grundmann GL, Moënne-Loccoz Y, SágováMarecková M. 2008. Development of a 16s rRNA gene-based prototype microarray for the detection of selected actinomycetes genera. Antonie van Leeuwenhoek 94(3):439-453. doi:10.1007/s10482-008-9261$\mathrm{z}$.

Lahdenperä ML, Simon E, Uoti J. 1991. Mycostop - a novel biofungicide based on Streptomyces bacteria. In: ABR Beemster, GJ Bollen, M Gerlagh, MA Ruissen, B Schippers, A Tempel, editors. Developments in agricultural and managed forest ecology. volume 23 of $B i-$ otic Interactions and Soil-Borne Diseases. Elsevier. p. 258-263. doi:10.1016/b978-0-444-88728-3.50048-2.

Li Q, Chen X, Jiang Y, Jiang C. 2016. Morphological identification of actinobacteria. In: D Dhanasekaran, Y Jiang, editors. Actinobacteria - basics and biotechnological applications. InTech. doi:10.5772/61461.

Macagnan D, Romeiro RdS, Pomella AWV, deSouza JT. 2008. Production of lytic enzymes and siderophores, and inhibition of germination of basidiospores of Moniliophthora (ex Crinipellis) perniciosa by phylloplane actinomycetes. Biol Control 47(3):309-314. doi:10.1016/j.biocontrol.2008.08.016.

Merckx R, Dijkstra A, Hartog Ad, Veen JAv. 1987. Production of root-derived material and associated microbial growth in soil at different nutrient levels. Biol Fert Soils 5(2):126-132. doi:10.1007/BF00257647.

Meschke H, Schrempf H. 2010. Streptomyces lividans inhibits the proliferation of the fungus Ver- ticillium dahliae on seeds and roots of Arabidopsis thaliana. Microb Biotechnol. 3(4):428-443. doi:10.1111/j.1751-7915.2010.00165.x.

Peiffer JA, Spor A, Koren O, Jin Z, Tringe SG, Dangl JL, Buckler ES, Ley RE. 2013. Diversity and heritability of the maize rhizosphere microbiome under field conditions. Proc Natl Acad Sci USA 110(16):6548-6553. doi:10.1073/pnas.1302837110.

Rovira AD. 1969. Plant root exudates. Bot Rev. 35(1):3557. doi:10.1007/BF02859887.

Sadeghi A, Hessan A, Askari H, Aghighi S, Shahidi Bonjar G. 2006. Biological control potential of two Streptomyces isolates on Rhizoctonia solani, the causal agent of damping-off of sugar beet. Pak J Biol Sci. 9(5):904-910. doi:10.3923/pjbs.2006.904.910.

Shimizu M. 2011. Endophytic actinomycetes: biocontrol agents and growth promoters. In: DK Maheshwari, editor. Bacteria in agrobiology: plant growth responses. Berlin, Heidelberg: Springer. p. 201-220. doi:10.1007/978-3-642-20332-9_10.

Shirling EB, Gottlieb D. 1966. Methods for characterization of Streptomyces species. Int J Syst Bacteriol. 16(3):313-340. doi:10.1099/00207713-16-3-313.

Singh BK, Millard P, Whiteley AS, Murrell J. 2004. Unravelling rhizosphere-microbial interactions: opportunities and limitations. Trends Microbiol. 12(8):386393. doi:10.1016/j.tim.2004.06.008.

Solans M, Vobis G. 2003. Saprophytic actinomycetes associated to the rhizosphere and rhizoplane of Discaria trinervis. Ecol Aust. 13:97-107.

Sreevidya M, Gopalakrishnan S, Kudapa H, Varshney R. 2016. Exploring plant growth-promotion actinomycetes from vermicompost and rhizosphere soil for yield enhancement in chickpea. Braz J Microbiol. 47(1):85-95. doi:10.1016/j.bjm.2015.11.030.

Sukamto, Wahyuno D. 2016. Identifikasi dan karakterisasi Sclerotium rolfsii Sacc. penyebab penyakit busuk batang nilam (Pogostemon cablin Benth) [identification and characterization of Sclerotium rolfsii Sacc., the cause of stem rot disease on Pogostemon cablin Benth]. Buletin Penelitian Tanaman Rempah dan Obat 24(1):35-41.

Tamura K, Peterson D, Peterson N, Stecher G, Nei M, Kumar S. 2011. MEGA5: molecular evolutionary genetics analysis using maximum likelihood, evolutionary distance, and maximum parsimony methods. Mol Biol Evol. 28(10):2731-2739. doi:10.1093/molbev/msr121.

Ting ASY, Hermanto A, Peh KL. 2014. Indigenous actinomycetes from empty fruit bunch compost of oil palm: evaluation on enzymatic and antagonistic properties. Biocatal Agric Biotechnol. 3(4):310-315. doi:10.1016/j.bcab.2014.03.004. 